\title{
Förändrad tillämpning av offentlig äldreomsorg - ett hot mot målsättningen om demokrati och jämställdhet
}

\author{
ANN-BRITT M SAND \\ Artikeln handlar om några effekter av den förändrade \\ inriktningen på det offentliga ansvaret för äldreomsorgen \\ och det är anhöriga till hjälpbehövande äldre \\ som står ifokus.
}

\begin{abstract}
Inledning
Två dominerande synsätt på äldre har kommit att prägla inriktningen av den offentliga äldreomsorgen. Det ena synsättet fokuserar äldre som en ömtålig och behövande grupp och var framträdande under 1950- och 60-talen (t.ex. SOU 1966:45). Den växande andelen äldre blev efterhand till en hotbild som ansågs komma att kräva alltmer samhällsresurser. Det är förklarligt att man behövde en motvikt till det så kallade "eländesperspektivet" (Tornstam 1993). Det andra synsättet, framträdande från 1970-talet och framåt beskriver istäl-

Ann-Britt Sand är fil.dr. i sociologi och forskarassistent vid Institutionen för socialt arbete, Umeå universitet.
\end{abstract}

let äldre som friska och aktiva, som en resurs i samhället (SOU 1977:98; prop. 1987/88:176; Odén, Svanborg, Tornstam 1993). Det är viktigt att lyfta fram att äldre inte bara är en skröplig grupp i behov av hjälp, utan såväl rehabiliterbara som kapabla till att göra självständiga val. Ett ökande tryck på individuellt ansvar för hälsa och omsorg ledde till nya tolkningar på hur man skulle definiera det offentliga ansvaret för äldre. Rehabilitering och pedagogik, hjälp till självhjälp, blev framträdande i synen på hur äldres hjälpbehov skulle tillgodoses. Att göra hälsa till ett individansvar riskerar emellertid att bortse från att äldre har levt, och lever, under olika villkor. Detsamma gäller anhöriga som i allt högre grad förväntas ta ansvar för sina hjälpbehövande 
äldre. Att anhöriga svarar för merparten av omsorgsinsatserna för äldre är väl känt (t.ex. Sundström 1983; Johansson 1991). På 1980-talet beräknades att anhöriga stod för två tredjedelar av all äldreomsorg (Johansson 1991). Idag kan man på goda grunder utgå ifrån att denna andel har ökat (Sand 2002, 2003). Trots detta konstaterar man i offentliga skrifter att framtidens äldreomsorg beror på tillgång till anhöriga och att anhöriga får räkna med ett större ansvar (t.ex. Socialstyrelsen 2000a; SOU 2000:7).

Den här artikeln ska handla om några effekter av den förändrade inriktningen på det offentliga ansvaret för äldreomsorgen och det är anhöriga till hjälpbehövande äldre som står i fokus. Bakgrunden till artikeln ligger i det faktum att det i Sverige har blivit allt svårare att få offentlig omsorg och att anhörigas insatser har ökat väsentligt. Det finns inte något som tyder på att den utvecklingen är på väg att ändras, eller att det sker något ifrågasättande av effekterna av ett ökat anhörigansvar ur ett jämställdhets-, demokrati- eller hälsoperspektiv.

I allt ökande grad håller den informella äldreomsorgen på att göras till en privat fråga som om den inte har något samband med den offentliga hjälpen. Syftet med artikeln är att ifrågasätta och diskutera förskjutningen av omsorgsansvaret från samhället till familjen och med fokus på anhörigvårdande kvinnors situation. Jag kommer att analysera effekterna av överföringen av arbete utifrån ett anhörigperspektiv, där kvinnor i yrkesverksam ålder är en grupp, och kvinnor i pensionsåldern är en annan grupp.

Frågor kring äldre och äldreomsorg beskrivs ofta på ett köns- och klassneutralt sätt (t.ex. äldre, anhöriga) trots att dessa tillhörigheter har stor betydelse i praktiken. Infallsvinkeln i artikeln ligger i det faktum att den offentliga hjälpens minskning fördelas köns- och klassmässigt olika. Det innebär att hemhjälpen, vid liknande behov, minskat mer bland kvinnor än bland män, och i synnerhet för kvinnor ur arbetarklassen (Szebehely 1993, 1998). Till detta kommer att framförallt kvinnliga anhöriga allt oftare räknas in vid beslut om personen ifråga ska få kommunal hjälp eller ej (t.ex. SOU 2001:79). Uttryckt på ett annat sätt verkar det vara så att sammanboende ej får hemhjälp om den hjälpbehövande är en man och har en hustru i hemmet. Ensamboende, och fr. a. kvinnor, får ej hemhjälp (eller mindre hemhjälp) om de har en dotter som bor i närheten. Dessa fenomen är vad som har utmärkt beslut om bistånd i form av hemhjälp under 1990-talet och framåt (mer än tidigare).

För att kunna diskutera effekterna av anhörigas ökande ansvar och arbetsbelastning görs först en kort beskrivning av viss lagstiftning samt av de förändringar som ägt rum i familjelivet under det senaste halvseklet. Detta har stor betydelse för den problematik som anhöriga ställs inför idag. Därefter följer ett avsnitt om den offentliga äldreomsorgens målsättning och tillämpning. Kommunernas anpassning till förändringarna diskuteras, det kommer främst att handla om biståndsbedömningarnas ändrade inriktning. Avslutningsvis tar jag upp anhörigvård och dess konsekvenser. Artikeln skrivs utifrån svenska förhållanden men i slutdiskussionen kommer jag att göra vissa internationella jämförelser. För artikelns syfte är det mindre intressant att ha en begreppsdiskussion om vad som 
är omsorg, vård eller hjälp. I det här sammanhanget menar jag att anhörigvårdarnas uppgifter innehåller samtliga delar och jag använder begreppen omväxlande i texten.

\section{Förändringar i familj och välfärdssystem}

Enligt lagstiftningen är äldreomsorg ett samhällsansvar. Innan 1956 låg huvudansvaret för äldreomsorgen på anhöriga. Barn skulle då ansvara för föräldrarnas försörjning. Genom den allmänna ålderspensionen (införd 1913) blev vuxna barns försörjningsansvar av marginell betydelse. År 1976 stärktes kommunens ansvar gentemot äldre genom skyldigheten att svara för boende och omsorg. I Sverige är det formellt alltså inte barn eller andra släktingar som har huvudansvar för de äldres välbefinnande, utan den offentliga sektorn genom kommunen (SOU 1997:170, s. 95).

I de nordiska välfärdssystemen är det individen, inte familjen, som är den minsta enheten. Skälen till detta är flera och har sin historiska bakgrund i uppbyggnaden av välfärdsstaten. Det har varit en politisk strävan att betona individen i välfärdssystemen. Att individen är minsta enhet betyder att den som har kvalificerat sig för arbetslöshetsförsäkring, sjukförsäkring eller liknande har rätt till ersättning, oavsett vad make eller andra familjemedlemmar tjänar. Egen skattepliktig inkomst krävs också för att få pensionspoäng. Det finns därmed tydliga drivkrafter för var och en att ha ett eget betalt arbete, vilket är grunden i socialförsäkringssystemen liksom i arbetsmarknadspolitiken.

Den individuella lagstiftningen har betydelse för familjelivet. Sverige brukar i internationella sammanhang lyftas fram som ett exempel på ett moderniserat familjeliv. Vad som särskilt betonas är de tydliga förändringarna i familjebildning och familjeupplösning, kvinnors höga förvärvsverksamhet och vår moderna lagstiftning och familjepolitik. Kvinnors förvärvsarbete kunde möjliggöras tack vare uppbyggnaden av en offentlig sektor. Genom utbyggnaden av den offentliga sektorn, som expanderade kraftigt under 1950- till 1970-talen, fördes arbetsuppgifter som tidigare utförts av kvinnor i hemmen ut på arbetsmarknaden. Det gäller exempelvis sjukvård, barn- och äldreomsorg. Samtidigt blev den offentliga sektorn en viktig arbetsplats för kvinnor.

Kvinnor i Sverige har i jämförelsevis hög utsträckning haft förvärvsarbete under lång tid. Det är också vanligare att lågutbildade kvinnor förvärvsarbetar jämfört med kvinnor $i$ andra länder. Sverige är sedan länge det land i EU som har lägst andel hemarbetande (hemmafruar). År 1999 utgjorde de ca 2 procent av kvinnor i förvärvsverksam ålder (SCB 2000). Även bland äldre kvinnor är andelen hemarbetande låg vilket skiljer Sverige och övriga nordiska länder från exempelvis länder i södra Europa (Stark och Regnér 2001).

Familjens roll och funktion har förändrats allteftersom samhället har förändrats. Den traditionella familjen med en manlig försörjare och en hemarbetande kvinna har ersatts av tvåförsörjarfamiljen (Björnberg 1992). Det innebär att både kvinnor och män förväntas bidra till familjens försörjning genom betalt arbete. Familjen är också mer heterogen än tidigare. Det har skett en ökning av separationer, ombildade familjer 
och ensamboende. Sådana förändringar gäller även för pensionärerna, tio procent är frånskilda och cirka 40 procent är ensamboende (SOU 2003:91, s. 540).

I svensk politik handlar det om att stärka individernas relativa oberoende inom familjerna. Familjen som social institution ses idag inte som en tillräcklig och tillförlitlig källa för att ge individerna försörjning, vård och omsorg. Välfärdsstaten kan därför ses som ett skydd för den enskilde individen oberoende av om denne har familj eller ej. Kommunal äldreomsorg kan således ses som ett av flera offentliga skydd för den enskilde individen.

\section{Svensk äldreomsorg - målsättning och tillämpning}

Huvudprincipen i den svenska äldrepolitiken är att äldreomsorgen skall vara solidariskt finansierad genom skattemedel och att den ska vara tillgänglig efter behov snarare än efter köpkraft (SOU 1997/98:113). De som själva kan betala ska inte ha företräde. Inte heller ska den offentliga äldreomsorgen främst inriktas på de allra fattigaste. Förutom att offentligt finansierad omsorg, vård och service ska vara tillgänglig för alla, ska den vara av god kvalitet. Äldre ska ges möjligheter att bo kvar i sitt hem. Vid behov av hjälp ska denna ges av kommunens hemtjänst och utifrån ett socialt perspektiv. Det är den enskildes behov som ska styra hjälpinsatsen.

Ser man till samtliga 1,5 miljoner ålderspensionärer har cirka 260000 regelbunden hjälp från samhället (SCB m.fl. 2000). Det motsvarar cirka 17 procent. Av dem som har hjälp har ungefär hälften hemhjälp, den andra hälften bor i någon typ av särskilt boende (sjukhem, gruppboende, ålderdomshem). Proportionerna har förändrats över tid mellan särskilt boende och eget hem. År 1980 var det dubbelt så många som fick hjälp i hemmet som det totala antalet platser i äldreboenden. Tjugo år senare var dessa grupper lika stora (eller små) (ibid. kap. 8).

Nedskärningarna började redan på 1970-talet men med ökad snabbhet under 1990-talet. Och trots att hjälpinsatserna har koncentrerats till de allra äldsta, är det färre också inom den gruppen som får del av den offentliga omsorgen. Åldersgruppen över 80 år har ökat med 48 procent sedan 1980 (Socialdepartementet 1997). Motsvarande åldersgrupp som får hemhjälp har däremot halverats; från 36 procent 1980 till 18 procent 2002 (Statistik socialtjänst 2003:3). Sverige är idag det land som ligger lägst i Norden när det gäller hjälp i hemmet (Szebehely m.fl. 1997).

Att färre får hemhjälp kan naturligtvis bero på minskade behov av hjälp. Det sker förändringar i levnadsvillkor och sjukdomsmönster över tid. Det fanns tidigare förhoppningar om att äldre skulle hålla sig friska allt längre under sin ålderdom. Det skulle i så fall förklara en del av minskningarna av hjälpen från hemtjänsten. Det stämmer också till viss del. Men minskade behov på grund av bättre hälsa svarar enligt beräkningar bara för cirka hälften av nedskärningarna (Batljan och Lagergren 2000). Nya indikatorer pekar på att hälsan bland de äldre inte utvecklas lika gynnsamt som tidigare (t.ex. Socialstyrelsen 2000a). Det finns också de som menar att klasskillnaderna vad gäller ohälsa bland äldre är oför- 
ändrat stora, och att den förbättrade hälsan främst gällde dem som i sitt yrkesliv varit tjänstemän (SCB m.fl. 2000). Det finns med andra ord skilda uppfattningar om hälsotillståndets utveckling bland äldre.

Det sociala perspektivet, som bland annat finns uttalat i propositionen för Ädelreformen (1990/91:14), har alltmer fått ge vika för ett medicinskt perspektiv. Idag är det de sjukvårdande insatserna som prioriteras. Det innebär att det är de vardagliga hjälptjänsterna (städning, tvätt, inköp, möjlighet att få komma ut etc.) som har minskat mest (SCB m.fl. 2000). Vad detta kan betyda ska jag återkomma till under rubriken "Konsekvenser för kvinnor i pensionsåldern".

Att ett medicinskt perspektiv har tagit över betyder dock inte att fler får institutionsvård. Den geriatriska sjukvården har minskat kraftigt under 1990-talet (Socialstyrelsen 2000a). Antalet sjukhusplatser inom geriatrik minskade mellan 1990 och 1997 från drygt 11000 till knappt 4000 platser. Den genomsnittliga vårdtiden på dessa platser minskade från 52 dagar år 1992 till 22 dagar 1996 (Szebehely 2000, s. 176). Det innebär att fler gamla allt oftare lämnar sjukhusen med kvarstående vårdbehov. Kopplat till den ökande svårigheten att få hemhjälp blir det en ekvation som inte går ihop om man ska leva upp till de mål lagstiftningen anger.

Det som har inträffat i praktiken är att det har skett en överföring av arbete och ansvar från det offentliga till bl. a. anhöriga. Man kan dock anta att nedskärningarna inom hemtjänsten får olika konsekvenser för olika människor och det gäller såväl dem som är hjälpbehövande som deras anhöriga.
Av rapporten Bo hemma på äldre da'r framgår att andelen som endast får hjälp av anhöriga, och alltså inte får någon kommunal hemhjälp alls, har ökat bland de gamla, jämfört med tidigare undersökningar (Socialstyrelsen 2000b, s. 36). Särskilt markant är ökningen bland gamla ur arbetarklass. Omsorgsarbete som tidigare utfördes av offentlig sektor utförs idag av anhöriga, förmodligen i någon liten utsträckning av frivilligorganisationer, och något av marknadsorganisationer. Frivilligorganisationer har tagit över vissa sociala inslag, som besök och promenader hos gamla. Städning har till viss del tagits över av marknadsorganisationer. Anhöriga har tagit över alla möjliga sysslor, när den offentliga vården och omsorgen allt mer kommit att syssla med medicinskt inriktade arbetsuppgifter för de allra äldsta (ibid.). Det är emellertid inte bara personer över 80 år som behöver hjälp. För dem i åldern mellan 70 och 76 år fördubblades hjälpinsatserna från anhöriga och vänner medan den sociala hemtjänstens insatser ökade endast marginellt (Steen 2003).

\section{Förändrad tillämpning}

Jag har hittills gjort beskrivningar utifrån tillgänglig statistik. Här ska jag söka visa vad som skett inom kommunerna vad gäller ansvarsfördelningen för äldreomsorgen. Biståndsbedömningarna har en avgörande, om än inte tillräcklig, förklaring till förändringen. Det är vid biståndsbedömningarna som den äldres tillgång till anhöriga i sin geografiska närhet, och om dessa anhöriga kan förmås bistå den behövande, vägs in vid kommunala beslut om hemtjänst. 
Biståndsbedömningar innebär att en kommunal tjänsteman gör ett besök hos den som ansökt om hjälp för att utröna vilka behov det rör sig om och vilken hjälp som är lämplig att ge, eller om det ska bli avslag på ansökan om bistånd. Det är den enskildes behov av hjälp som ska styra insatsen. I socialtjänstlagens paragraf 6 står att "Den som inte själv kan tillgodose sina behov eller få dem tillgodosedda på annat sätt har rätt till bistånd av socialnämnden för sin försörjning (försörjningsstöd) och för sin livsföring i övrigt (annat bistånd) på de villkor som anges i §§6b-6 f " (Svenska kommunförbundet 1998, ss. 17 och 18). Där står även, under rubriken Hushållsgemenskap, att "...Det bör också kunna beaktas att man normalt ger varandra viss praktisk hjälp i familjen. Däremot kan inte mera omfattande vårdbehov anses ligga inom vad man normalt bistår varandra med inom en familj.» (Ibid. s. 19).

Det är emellertid konstaterat att man vid biståndsbedömningar oftare har utgått från tillgängliga resurser istället för befintliga behov. Gapet mellan den andel äldre som behöver hjälp och den som verkligen får det är stort. Socialstyrelsen konstaterar i en rapport om obalansen mellan omsorgsbehov hos äldre och ekonomiska resurser, att handläggare inom äldreomsorgen allt oftare hoppar över att bedöma de äldres behov och istället koncentrerar sig på de insatser som kan göras (Socialstyrelsen 1997, s. 62). Det har också visat sig att ekonomisk behovsprövning, där hjälpbehov ställs mot den hjälpsökandes inkomster, förekommer (Szebehely 2000). Ekonomisk behovsprövning innebär att den som anses ha råd får köpa sin hjälp på annat sätt än via kommu- nens hemtjänst. Detta sker trots att det inte är vare sig brist på, eller tillgång till, egna medel som ska vara utslagsgivande för att få hemhjälp.

För att återknyta till inledningskonstaterandet skiljer sig praktiken inom kommunernas hemhjälp åt. Det finns stora skillnader i bedömningar mellan olika kommuner (t.ex. Bender 1991; Mossberg 1994; Lindelöf och Rönnbäck 1997; Socialstyrelsen 1997). Det finns skillnader mellan hur gamla och deras anhöriga kan förhandla med kommunen. Det finns också genusbaserade skillnader mellan hur framför allt kvinnliga och manliga anhöriga förväntas agera, och vilket ansvar de förmodas ta. Flera indikatorer pekar mot att förekomsten av döttrar bedöms annorlunda än förekomst av söner. Om en dotter finns i geografisk närhet av den gamla anses hon vara lämplig som vårdare oftare än om en son finns där. Förändringarna inom den kommunala hemtjänsten har därmed gett effekter som går åt två olika håll. De äldre som har möjlighet köper tjänster på marknaden. De som inte har sådana resurser får antingen vara utan hjälp eller förlita sig på sina närstående. Denna pågående trend har kallats "marknadisering" respektive "informalisering" av äldreomsorgen (Szebehely 1998a). Man kan se att särskilt resurssvaga äldre har fått mindre hjälp inom äldreomsorgen än tidigare. Det hänger samman med att resursstarka äldre ofta kan vara bättre på att förhandla sig till hemtjänsttimmar, men också att de lättare kan köpa privat hjälp på marknaden (ibid.). Detta torde innebära att resursstarka personer kan få den nödvändiga hjälpen från två håll, marknaden och hemtjänsten. Mindre resursstarka har svårt 
att kräva hjälp om de får avslag vid biståndsbedömningen samtidigt som de inte har tillräckligt god ekonomi för att köpa den hjälp de behöver på marknaden. Den snävare tilldelningen av omsorg har därmed medfört större ojämlikhet mellan grupper av äldre. Män är underrepresenterade och kvinnor dominerar inom alla resurssvaga grupper (Socialstyrelsen 1997).

De förändringar som skett inom hemtjänsten innebär ett avsteg från den nordiska modellen med individen snarare än familjen som minsta enhet i socialpolitiska sammanhang (Mossberg 1996, Mossberg Sand 2000; Szebehely 2000).

\section{Anpassning och överföring av ansvar}

Hur kunde då ansvarsfrågan skjutas tillbaka till familjen? Eller snarare till en person i familjen eftersom det vanligen är en individ det handlar om, inte något familjekollektiv (Mossberg 1994). Den viktigaste förklaringen är att det har skett en förskjutning $i$ fråga om vem som anses ha ansvar för hjälp till äldre. Anhörigas ansvar ökade som en följd av lågkonjunkturen och den ekonomiska krisen i kommunerna under 1990talet. Kommunerna skulle spara pengar och tvingades dra ner på olika utgifter. Det gällde alla områden, men inte minst social hemtjänst. Tillämpningen av lagen kom därmed att förändras. Socialtjänstlagen är en ramlag och ger utrymme för tolkning. Kommunens ansvar sägs bara gälla »om behovet ej kan tillgodoses på annat sätt». Det är här som anhöriga kommit in som en slags outnyttjad resurs. Äktenskapsbalken används ibland också som påtryck- ningsmedel. Makar (och framför allt fruar) uppmärksammas på att de som gifta har ett särskilt ansvar att stödja och hjälpa varandra (Mossberg Sand 2000). De senaste åren har ekonomin blivit bättre och det har skett en liten ökning av kommunernas utgifter för äldreomsorg. Att anhöriga måste ta sitt ansvar är dock en "etablerad sanning" och ingen biståndsbedömare verkar idag ifrågasätta sin rätt att lägga arbete på anhöriga, framför allt på kvinnor. Personal som arbetar med äldreomsorg är till stor del kvinnor. Att vara kvinna är emellertid ingen garant för att vare sig veta vad andra kvinnor vill, kan eller behöver.

Naturligtvis kan inte biståndsbedömare agera oberoende av kommunens policy och ekonomi. De ska hålla budgeten, eller minska utgifterna, samtidigt som behoven och kraven på hjälp ökat. Man får snarare se deras agerande som ett sätt att hantera en tämligen omöjlig situation. Om man under lång tid håller på med nedskärningar och avgränsningar i vad som är behov finns emellertid risk för att högst berättigade önskemål om hjälp definieras bort. Speciellt om det finns minsta chans att någon annan kan utföra dem. Det blir lätt så att de som klarar av att hävda sin rätt till hjälp får den, medan de som saknar den förmågan blir utan. Även om man både kan och bör ifrågasätta biståndsbedömningarna, är det inte denna personal som ska stå till svars för den utveckling som lägger över ansvaret på anhöriga. Det är istället en övergripande samhällelig och politisk fråga: Vem ska stå för äldreomsorgen? Och till vilket pris? Är det exempelvis rimligt att kommunerna, med sina olika förutsättningar, ska klara av att uppfylla lagstiftningens målsättningar utan statlig hjälp? 


\section{Varför det är enkelt att lägga över arbete på anhöriga}

I internationell litteratur finns det belägg för att det finns starka förväntningar på kvinnor att ställa upp för släkt och vänner. Dessa förväntningar kommer både från omgivningen och från kvinnorna själva (se t ex Finch och Mason 1993; Ungerson 1990). I Sverige med vår utbyggda offentliga vård och service och inriktning på att kvinnor ska lönearbeta har man antagit att sådana krav inte är lika starka. Men kvinnor och män har olika yrkesområden och omsorgsarbete för familjen och släkten vilar fortfarande till största delen på kvinnorna. De arbetsuppgifter som de då utför uppfattas som så självklara, även för kvinnorna själva, att de ofta inte nämns som nödvändigt arbete. När en kvinna som har en hjälpbehövande man fortsätter att utföra det hushållsarbete hon redan tidigare utfört, så betecknar hon det inte som äldreomsorg. När en man utför samma arbetsuppgifter för sin maka, arbetsuppgifter som hon tidigare utfört men nu inte längre klarar, så betecknar han dessa arbetsuppgifter som äldreomsorg (Hansson, Jegermalm och Whitaker 2000). Detta kan möjligen vara en bidragande förklaring till varför män som ger anhörigvård kan få hjälp från hemtjänsten medan kvinnor i motsvarande situation har svårare för att få det. Arbetet måste synliggöras och värderas.

Det finns flera förklaringar till varför det är enkelt att lägga över arbete på anhöriga och där kärlek, sociala normer, pliktkänsla med mera ingår. En viktig förklaring är dock att det är hushållsarbetet och de sociala omsorgsuppgifterna som har definierats bort från den kommunala hemtjänstens ansvarsområde för äldre som har anhöriga. Så länge dessa uppgifter inte ses som arbete, eller värderas utifrån samma normer som ett lönearbete, är det svårt att hävda att det är en verksamhet som tar tid och kraft.

\section{Vad innebär anhörigvård?}

Anhörigvårdarnas arbete påminner om det arbete som hemtjänstpersonal utför men det finns också viktiga skillnader. En undersökning om påfrestningar i hemtjänsten (Thulin, 1992) visar att detta kvinnodominerade arbete är lika tungt, till och med tyngre, än vad som gäller $\mathrm{i}$ klassiska exempel på tunga manliga jobb. Tungt arbete är utmärkande för många anhörigvårdares situation, skillnaden vid jämförelse med hemtjänstpersonal är att de inte kan gå ifrån arbetet, arbetsdagen har inget slut om de bor ihop med sin vårdtagare (Mossberg 1996). För anställd personal gäller att utbildning och medbestämmande i planeringen av arbetet tar tid från antalet vårdtimmar, vilket leder till att utbyggd vård inte alltid innebär fler vårdtimmar (se Gough 1987, Szebehely \& Eliasson 1991). Det finns inte samma omtanke om dem som vårdar sina anhöriga. De lever ofta under stark press och det ställs stora krav på dem från flera håll. Många känner sig isolerade, trötta och har svårt att få vila eller semester. Kari Wærness (1985) visar i en undersökning hur döttrar som har huvudansvaret för vårdkrävande föräldrar upplever sitt deltidsarbete som städerskor eller nattvak på sjukhus som "fritid" jämfört med anhörigvårdsituationen. Liknande resultat framkom i en undersökning 
om anställda anhörigvårdare (Mossberg Sand 2000).

Det finns entydiga forskningsresultat (se t ex Finch and Groves 1983; Winqvist 1985; Zarit m.fl. 1986; Johansson 1991; Mossberg Sand 2000; Jeppsson Grassman m.fl. 2003) som visar att arbetet som anhörigvårdare ofta är fysiskt och psykiskt betungande. Det kan leda till ensamhet och isolering genom ett dygnet-runt-ansvar för den vårdbehövande. Ekonomin kan försämras av olika skäl. Den anhörige måste kanske minska i lönearbetstid för att klara av omsorgsbehovet (Mossberg 1996; Mossberg Sand 2000). Men ekonomin kan också försämras av skälet att det blir många omkostnader om det finns en sjuk och/eller handikappad person i familjen. Man vet att anhöriga inte gärna ber om hjälp vilket delvis handlar om att deras egen situation som omsorgsgivare är så påfrestande att de inte orkar ta kontakt eller ta hänsyn till egna behov.

Baila Miller (1990) undersöker hur vård av anhöriga påverkar vårdgivaren, och hon skiljer på egen tidsplanering, egen hälsa och emotionella påfrestningar. Hon undersöker endast de fall där makan/maken är vårdgivaren. I jämförelser mellan mäns och kvinnors möjligheter att styra sin tidsanvändning finner hon inga skillnader, däremot är skillnaderna i konsekvenser för vårdarens hälsa mycket tydliga. Kvinnors hälsa påverkas negativt $\mathrm{i}$ högre utsträckning än männens i motsvarande informella vårdsituation. I en annan undersökning framstod ekonomisk ersättning, uppskattning, en god relation till den anhörige och ömsesidighet som de viktigaste komponenterna för att orka med vården av den anhörige (Mossberg Sand 2000). Att dela ansvaret med någon (t.ex. personal i hemtjänsten) hade en positiv inverkan på oro och stress. Behovet av hjälp hade dock en avgörande betydelse för hur man såg på sin situation. De som upplevde sig behöva mer hjälp $i$ arbetet hade svårare för att ta till sig de positiva sidorna.

\section{Konsekvenser för kvinnor i pensionsåldern}

Den demografiska utvecklingen har medfört att fler äldre än tidigare har blivit vårdare. Pensionärer sköter om andra pensionärer. Mellan 15 och 20 procent av dagens nyblivna pensionärer har minst en av sina egna föräldrar kvar i livet (regeringens prop. 1997/98:113, s. 28). De ökande livslängderna har gjort att kvinnor i dessa åldrar i praktiken samtidigt kan ha omsorgsansvar för sin make, sina föräldrar och delvis för sina barnbarn (ibid.).

De flesta undersökningar pekar på att hustrur utför mycket mer äldreomsorg för sina män än männen gör för hustrurna (t.ex. Finch och Mason 1993; Mossberg Sand 2000; Demensförbundet 2003). Med ökad livslängd bland män har det troligen skett en ökning även av manliga anhörigvårdare. Det finns dock olika förväntningar på kvinnor och män både vad gäller att utföra hemarbete som vård av anhöriga. Neddragningarna inom den kommunala hemtjänsten har i hög grad har drabbat sammanboende kvinnor (Szebehely 1998b). Om det är kvinnan som är hjälpbehövande är det dubbelt så vanligt att paret har hemhjälp jämfört med om det är mannen som behöver hjälp. Motsvarande gällde den hjälp som vuxna barn och andra anhöriga gav. Det var tre gånger vanligare att barnen hjälpte ett gift 
äldre par om det var kvinnan som var den hjälpbehövande än om det var mannen som behövde hjälp (ibid. s. 145). En gift kvinna står därför mer ensam med omsorgsarbetet än en gift man i samma situation.

Att begäran om hemhjälp avslås med hänvisning till att det finns en frisk person i hushållet är inget nytt (Szebehely 1993; Szebehely m.fl. 2001). Det nya är att definitionen på frisk har vidgats; d.v.s. hänsyn till den anhöriges ålder och eget hälsotillstånd verkar inte förekomma. Att inte ta hänsyn till den äldre som förväntas utföra arbetet innebär flera problem. Ett problem är att rent fysiskt är män vanligen tyngre än kvinnor vilket får konsekvenser för den hustru som ska ge lyfthjälp (Mossberg 1996). Att ensam hjälpa sin make ur sängen, ur stolar o.d. ger inte sällan förslitnings- och belastningsskador. I en undersökning om vårdupplevelser bland äldre förekom kvinnor som vid upprepade tillfällen fătt urledvridna axlar i sådana lyftsituationer (Mossberg och Tegner 1988).

Flertalet av kvinnorna som är anhörigvårdare för sina män är själva pensionärer. Det är därför viktigt att påtala att kvinnors kraft i den här åldern kan vara starkt nedsatt. I en longitudinell studie om äldre påpekas att trots den högre förekomsten av hjärtkärlsjukdom hos män och det faktum att åldrandeförändringar i hjärtkärlsystemet uppträder tidigare hos män än hos kvinnor, är det tydligt att män har en bättre fysisk prestationsförmåga än kvinnor, också i hög ålder (Steen 2003). De flesta 75-åringarna klarade sig utan hjälp från omgivningen. Men det var påtagligt många av kvinnorna som hade en arbetskapacitet så låg att den torde begränsa ett aktivt liv (ibid. s. 111).
Den typ av hjälp som minskat mest inom den offentliga hemhjälpen är praktisk hjälp med vardagssysslor (SCB m.fl. 2000; Szebehely 2000). Det är just den sortens hjälp som efterfrågas mest bland äldre. Här kan det vara värt att notera de klass- och könsskillnader som konstateras i en undersökning om äldres levnadsförhållanden (SCB m.fl. 2000). Där framkom att äldre ofta behöver hjälp med vardagligt hemarbete. Man skriver vidare att förekomsten av funktionsnedsättningar varierar mellan olika befolkningsgrupper. Rörelsehinder är vanligare bland pensionerade arbetare än bland pensionerade tjänstemän medan synförsämringar drabbar båda grupperna tämligen lika. Förekomst av fysiska funktionsnedsättningar skiljer mycket mellan kvinnor och män och är starkt relaterade till ålder. Fram till 75-årsåldern har var femte kvinna problem att bära fem kilo. I åldern 75-84 år rapporterar däremot över 40 procent av kvinnorna sådana besvär. Bland männen är det avsevärt färre som får problem att bära tungt. Man konstaterar att armstyrka förefaller stå männen bi avsevärt högre upp i åldrarna än kvinnorna (ibid. s. 170). Skillnaderna mellan män och kvinnor är mindre tydlig när det gäller funktionsförmåga $i$ benen. Bland de yngre pensionärerna är det inte stora könsskillnader då det gäller att gå i trappor eller kortare promenader. I åldern 75-84 år finns däremot en klar skillnad. Nästan 40 procent av kvinnorna mot 22 procent av männen har problem med trappor. Svårast att röra sig har de som har haft ett arbetaryrke.

I en undersökning om anhörigvård, och där flera relationsformer och åldrar ingick, framkom att de som hade svårast för att ta 
till sig de positiva sidorna av arbetet var just gamla kvinnor som hjälpte sin make (Mossberg 1996, Mossberg Sand 2000). Skälen var framför allt att kvinnorna upplevde bristande kapacitet, kombinerad med för lite eller ingen hjälp alls från hemtjänsten, samtidigt som de uppgav behov av hjälp. Det framkom att flera av dem var deprimerade och uttröttade av tvätt, blöjbyte, tunga lyft, av- och påklädning samt ofta också ständig passning av sin make. En del av dem upplevde dessutom maken som en främling på grund av den personlighetsförändring som vissa sjukdomar medför. Det är kanske inte så märkligt att dessa kvinnor önskade sig ett annat liv på sin ålderdom (Mossberg 1996, ss. 114-130).

Äldre kvinnor verkar generellt ha en sämre fysisk prestationsförmåga än äldre män, och de har svårare för att bära tunga saker. Speciellt gäller detta om de har haft ett arbetaryrke. Trots det har äldre kvinnor fått större minskningar av kommunal hemhjälp jämfört med äldre män. Det tycks gälla både när de är anhörigvårdare för sin make och när de själva som ensamstående upplever ett hjälpbehov. Orsaken till mindre eller ingen hjälp handlar troligen om könsbundna förväntningar på vad kvinnor respektive män ska klara av. Bedömningarna av behoven tycks i varje fall ha mycket lite med de faktiska förhållandena att göra, eller behoven respektive förmågan, hos den som får utföra arbetet.

\section{Konsekvenser för kvinnor $\mathrm{i}$ yrkesverksam ålder}

Om äldre kvinnor har problem med egen hälsa och bristande krafter finns det andra problem för de yngre. Kvinnor i Sverige förvärvsarbetar i ungefär samma utsträckning som män. Om det uppstår ett hjälpbehov och den tänkta anhörigvårdaren är i arbetsför ålder ställs hon inför en komplicerad situation. Det är av flera skäl viktigt för svenska kvinnor att ha ett förvärvsarbete och det finns för närvarande inga tecken på att man lämnar arbetsmarknaden helt för att bli anhörigvårdare, åtminstone inte för äldre släktingar. Många försöker istället kombinera förvärvsarbete med ibland omfattande anhörigvård.

För vissa kvinnor blir kanske deltidsarbete en utväg. Det är dock en lösning som de själva betalar dyrt för i form av lägre inkomster och i form av framtida lägre pension. Ingrid Palmer (1995) har analyserat obetalt omsorgsarbete som en social skatt på kvinnor, en individuell skatt som dels utgår i form av det obetalda arbete som kvinnor har att utföra innan en egen inkomst blir möjlig, dels i form av deras sämre villkor på den betalda arbetsmarknaden.

Problematiken förvärvsarbete - anhörigvård uppmärksammades tidigt av politiker och i slutet av 1970-talet tillsattes en statlig kommitté för att se över stödet till dem (SOU 1983:64). Ett sätt att stödja anhörigvårdare är att ge dem anställning och lön. Sådan anställning innebär en form av kontrakt med kommunens hemtjänst och att lön utbetalas till den anhörige som utför arbetet. Genom anställningen finns en koppling till socialförsäkringssystemet och man drabbas därmed inte lika svårt ekonomiskt som en obetald anhörigvårdare. I en undersökning om anställda anhörigvårdare (1197 respondenter) framkom att 85 procent av 
dem var kvinnor, och att de vanligen hade ett arbetaryrke eller var lägre tjänstemän (Mossberg Sand 2000). Majoriteten av dem hade förvärvsarbete vid anhöriganställningens början. På grund av svårigheterna med att förena omsorg med förvärvsarbete - att man inte orkade med dubbelarbetet, att den anhörige behövde ständig hjälp och tillsyn, att lönearbetstid och omsorgstid inte fungerade tillsammans - hade majoriteten minskat i förvärvsarbetstid eller helt slutat arbeta. Anställningen som anhörigvårdare gav dem en inkomst och en möjlighet att hantera situationen, och det var en mycket uppskattad form av hjälp.

De anställda anhörigvårdarnas antal har emellertid stadigt minskat från cirka 20000 på 1970-talet till 2081 personer år 2002 (Statistik socialtjänst 2003:3). Även andra ekonomiska ersättningar till vårdande anhöriga har minskat. Kontantbidrag är en typ av ersättning som ges till den hjälpbehövande för att ersätta någon anhörig. År 1982 fick 21000 personer sådant bidrag. År 1995 hade de minskat till 7000 (Johansson 1997), och år 2002 var de 5513 (Statistik socialtjänst 2003:3).

Den betalda anhörigomsorgen har således minskat samtidigt som också de kommunala hemhjälpsinsatserna har minskat bland äldre som får anhörigomsorg. Detta har, paradoxalt nog, skett samtidigt som det samhällets ansvar att stödja anhöriga som vårdar har uppmärksammats mer än tidigare i statliga policydokument. Det har återkommande påpekats att anhörigas insatser ska bygga på frivillighet och att de bör få hjälp och stöd från kommunen i sitt arbete (t.ex. SOU 1983:64; SOU 1994:139; Svenska kommunförbundet 1998). Till hjälp och stöd hör även ekonomisk ersättning. „I den mån samhället engagerar anhöriga $\mathrm{i}$ vårdarbetet bör de få adekvat ersättning för sitt arbete. Vi anser det vara angeläget att de anhöriga får en rimlig ekonomisk situation under vårdtiden och därmed ett bättre pensionsutfall«(SOU 1994:20, s. 186).

\section{Diskussion}

När Stark och Regnér (2001) jämför äldreomsorg i tre EU-länder (Tyskland, Spanien och Sverige) hittar de flera likheter mellan svensk och tysk äldreomsorg trots att lagstiftningen skiljer sig åt. I sin praktiska tillämpning närmar sig tysk och svensk äldreomsorg varandra, men från olika utgångspunkter. Det formellt beslutade systemet står i bägge länderna ganska långt ifrån verkligheten. I Sverige förefaller gapet mellan regler och praktisk tillämpning vara störst. Individuell bedömning har ersatts av en familjemodell, beslutsprocessen underlättar inte insyn eller synpunkter från den äldre och de anhöriga, och tillämpningarna är mycket olika både regionalt, inom samma region och om kvinnliga eller manliga anhöriga till den vårdbehövande finns i närheten. Genom 1990-talets nedskärningar menar de att den svenska äldreomsorgen har kommit att likna den tyska och den spanska i så måtto att anhörigas obetalda insatser blivit allt viktigare (ibid. ss. 196-204).

Det finns en inneboende motsättning i dagens familjeliv och arbetsliv och det är hur individens frihet och rättigheter ska kunna kombineras med omsorgen om äldre och hjälpbehövande. Vårt välfärdssystem är uppbyggt kring att den offentliga sektorn står för omsorg om barn och gamla och att 
kvinnor och män i yrkesverksam ålder finns på arbetsmarknaden. Det är den enskildes arbete och inkomst som räknas i socialförsäkringssystemet. Att lägga över mer arbete på anhöriga ger därför följder på flera olika sätt. Om förmågan att ge omsorg ses som självklar och oproblematisk har man bortsett från andra krav som ställs på individen $\mathrm{i}$ dagens samhälle. Nedskärningar av offentlig äldreomsorg får effekter för de jämställdhetssträvanden som varit ett honnörsord i svensk politik.

Sverige är det enda land i världen där kvinnor och män lämnar förvärvslivet vid samma ålder (Stark och Regnér 2001). Och den åldern ligger över det europeiska genomsnittet. I dag förs diskussioner om att höja pensionsåldern, bl.a. av skälet att hålla igång den offentliga sektorn. Det är många, och framför allt kvinnor, som kommer att få mycket låga pensioner på grund av ändrade regelsystem. Vilka kvinnor som kommer att kunna stanna i förvärvsarbete till 67 år kommer att vara starkt klassbetingat menar Stark och Regnér. Kvinnor och män har formellt sett fått samma möjligheter men lever inte i samma verklighet. Hur avvägningen mellan individualitet och omsorg ser ut får avgörande konsekvenser för hur familjeansvaret fördelas. Det statliga regelverket tar inte hänsyn till att kvinnor fortfarande tar ett mycket större ansvar för det obetalda arbetet hemma. Enbart förvärvsarbetet anses värdefullt och ger något tillbaka och därför får deltidsarbetande kvinnor lägre pension. Med lägre pension blir det svårt att finansiera den hjälp som alltmer verkar bli en marknadsfråga. Det förefaller därmed som att vissa får betala för att ge anhörigvård men när de sedan själva behöver hjälp har de troligtvis inte råd att köpa den. Eftersom reglerna är könsneutrala ses effekterna som ett uttryck för individens fria val: kvinnor får skylla sig själva. Man bortser helt från det sociala normsystem som är långt starkare än de politiska ambitionerna om jämställdhet (ibid. ss. 191-195).

I länder med familjeansvar för åldriga släktingar finns andra regler för socialpolitik och arbetsmarknadspolitik. Vård av en anhörig kan ge lön, bidrag eller medföra lägre skatt. USA har ett uttalat familjeansvar. Med en ökande andel pensionärer börjar alltfler anhöriga få en problematisk situation i förhållande till arbetslivet. Anhörigföreningar gör påtryckningar om att arbetsgivarna ska ta hänsyn till att deras arbetstagare har gamla föräldrar, dvs. ge rätt till ledighet och rätt att minska i arbetstid för anhörigvård. I vissa stater har ett sådant arbetsgivaransvar införts i lagen (Coleman 2004). Det finns också möjligheter till skattelättnader vid vård av anhöriga, och lön för anhörigvård är en fråga man på allvar börjat diskutera. Liknande diskussioner finns i flera länder och England har under 2004 infört en lag som bl.a. ger möjlighet till lön för anhörigvård (www.carersonline. org.uk.).

I Sverige finns en hel del rekommendationer om hur man ska kunna hjälpa anhöriga men dessa rekommendationer har föga verkan om de inte följs. 1990-talet har visat hur känsligt välfärdssystemet är för ekonomiska förändringar. I den nya socialtjänstlagen står att kommunerna bör hjälpa anhöriga som vårdar, men det står bör, inte skall, vilket hade varit mer förpliktigande. Att lagen inte ställer större krav innebär också att hjälpen ser olika ut beroende på var i 
landet man befinner sig. Vissa kommuner ger lite eller ingen hjälp alls till anhöriga. Andra kommuner har kanske anhörigkonsulenter för att hjälpa och stödja anhörigvårdare, eller försöker på annat sätt bygga upp en stödverksamhet. I en skrift från Socialstyrelsen (2002) beskrivs en kommun som bl.a. ger anhörigvårdarna 12 timmars avlösning per månad, utan kostnad för avlösningen vilket annars är det normala. Denna kommun framställs som en av de mer progressiva kommunerna. Att samhället skulle ta sitt fulla ansvar för äldreomsorgen verkar däremot inte vara någon aktuell politisk fråga.

Att vara frisk och självständig betyder inte att man inte kan bli sjuk och beroende. Som i alla andra åldersgrupper innehåller gruppen äldre människor med olika förmågor och olika behov. Den kommunala hemhjälpen ska underlätta hemmaboende. En grundläggande förutsättning för att klara av eget boende trots hjälpbehov, är att få hjälp med bl.a. hushållsarbete. Vem som ska utföra arbetet handlar även om de äldres integritet och valfrihet. Man kan fråga hur det påverkar gamla människor att åter bli beroende av sina anhöriga för hjälp. I vårt samhälle värderas oberoende och självständighet högt. Gerontologisk forskning har visat att förlust av självständighet och ett ökat beroende av andra leder till känslor av otillräcklighet och minskat välbefinnande. Detta gäller även ökat beroende till barn och/eller nära anhörig (t.ex. Daatland 1990; Thorslund och Larsson 2002). Undersökningar visar att äldre föredrar offentlig hjälp framför anhörigas insatser (t.ex. Svallfors 1996). Det handlar bl.a. om att man vill ha en annan typ av relation med sina anhöriga (frivilligt umgänge, vänskap).

Nedskärningar inom den offentliga omsorgen måste ses, inte bara som en fråga om kommunal ekonomi utan i ett samhällsperspektiv. På ett annat plan handlar det också om att söka förstå vad skillnaderna mellan ideal, lagstiftning och praktik kan betyda för tilltron till välfärdssamhällets löften om en trygg ålderdom. Vad innebär det för lojaliteten med välfärdssamhället, och inte minst för skattemoralen, att inte kunna lita på att den lagstiftning som finns är stark nog att ge individen hjälp på äldre dar? 


\section{Referenser}

Bender, Birgitta (1991). Pensionärslotteriet? Behovsbedömning inom hemservice. FoU-Rapport $\mathrm{Nr}$ 1991:2. Stockholms socialförvaltning.

Björnberg, Ulla (1992). Tvåförsörjarfamiljen i teori och verklighet. I Acker Joan m fl: Kvinnors och mäns liv och arbete. SNS Förlag, ss 153-218.

Batljan, Ilija och Lagergren, Mårten (2000). "Kommer det att finnas en hjälpande hand". Bilaga 8 till Långtidsutredningen. ISOU 2000:7. Stockholm: Socialdepartementet, Långtidsutredningen 1999/2000b.

Coleman, Barbara (2004). Navigating the care system: A guide for providers to help family caregivers. Family Caregiver Alliance. National Center on Caregiving.

Daatland, Svein Olav (1990). What are families for? On family Solidarity and Preference for help. I Ageing and Society; vol 10, 1, s 1-5.

Demensförbundet (2003). Demensförbundets anhörigenkät. Sammanställning, mars 2003.

Finch, Janet \& Groves, Dulcie (ed.) (1983). A Labour of Love: Women, Work and Caring. London: Routledge \& Kegan Paul.

Finch, Janet and Mason, Jennifer (1993). Negotiating family responsibilities, London and New York: Tvistock/Routledge.

Gough, Ritva(1987). Hemhjälptill gamla. Forskningsrapport nr 54. Arbetslivscentrum Stockholm.

Hansson, Jan-Håkan, Jegermalm, Magnus och Whitaker, Anna (2000). Att ge och ta emot hjälp. Anhöriginsatser för äldre och anhörigstöd - en kunskapsöversikt. Sköndalinstitutets arbetsrapportserie nr. 15.

Jepsson Grassman, Eva (red.) (2003) Anhörigskapets uttrycksformer. Lund: Studentlitteratur.

Johansson, Lennarth (1991). Caring for the Next of Kin. On Informal Care of the Elderly in Sweden. Department of Social Medicine. Uppsala. (Akademisk avhandling).

Johansson, Lennarth (1997). Anhöriga och frivilliga - lösningen på äldreomsorgens problem? I Jennerbert, K \& Lagerkrantz, R (ed.). Äldrepolitik i förändring. Skriftserien Välfärdsprojektet. Socialdepartementet.
Lindelöf, Margareta och Rönnbäck, Eva (1997). Behov, bedömning och beslut I äldreomsorgen. En studie I 27 kommuner kring handläggningsprocessen. SoS-rapport 1997:8. Stockholm: Socialstyrelsen.

Miller, Baila (1990). Gender differences in Spouse caregiver Strain: Socialization and Role explanations. Journal of Marriage and the Family. 52 May 1990: 311-321.

Mossberg, Ann-Britt och Tegner, Elisabeth (1988). Vårdupplevelser bland äldre i Kortedala. I Äldrestudien. Delrapporter. Göteborgs sjukvård, Socialtjänst Göteborg och Göteborgs stadskansli.

Mossberg, Ann-Britt (1994). De anhöriganställdas vardag. Ädelutvärderingen 1994:1. Socialstyrelsen.

Mossberg, Ann-Britt (1996). "Jag tar en dag i sänder" - om ålderspensionerade anhörigvårdare. I Elisasson, R. (red.). Omsorgens skiftningar - Begreppet, vardagen, politiken, forskningen. Lund: Studentlitteratur.

Mossberg Sand, Ann-Britt (2000). Ansvar, kärlek och försörjning. Om anställda anhörigvårdare $i$ Sverige. Department of Sociology. Göteborg University. (Akademisk avhandling).

Odén, Birgitta, Svanborg, Alvar, Tornstam, Lars (1993). Att alldras i Sverige. Bokförlaget Natur och Kultur.

Palmer, Ingrid (1995). „Public finance from a gender perspective« s. 1981-86 i World Development Vol. 23 No.11

Regeringens proposition 1997/98:113. Nationell handlingsplan för äldrepolitiken.

Sand, M. Ann-Britt (2002). Anhörigvård. Lund: Studentlitteratur.

Sand, M. Ann-Britt (2003). Var finns de gamla I den svenska familjen? I Kollind, A-K. and Peterson, A. (red.). Thoughts on Family, Gender, Generation and Class. Department of Sociology. Göteborg University.

SCB, Socialdepartementet och Socialstyrelsen (2000). Äldres levnadsförhållanden 1980-1998. Rapport 93. Stockholm: SCB.

Ann-Britt M Sand: Förändrad tillämpning av offentlig äldreomsorg - ett hot mot... 
SCB 2000. På tal om kvinnor och män. Lathund om jämställdhet. Örebro: SCB.

Socialdepartementet (1997). Välfärdsfakta social - sammanställning av fakta/nyckeltal inom välfärdsområdet. LA-sekretariatet.

Socialstyrelsen 1997. Behov Bedömning Beslut $i$ äldreomsorgen. SOS-rapport 1997:8. Stockholm: Socialstyrelsen.

Socialstyrelsen 2000a. Äldreuppdraget. Slutrapport. Socialstyrelsen följer upp och utvärderar. Rapport 2000:4. Stockholm.

Socialstyrelsen 2000b. Bo hemma på äldre da'r. Äldreuppdraget 2000:11. Stockholm.

Socialstyrelsen 2002. Anhörig 300-Slutrapport.

Socialstyrelsen 2004. Vård och omsorg om äldre. Lägesrapport 2003.

SOU 1966:45. Aktiv åldringsvård och handikappvaird.

SOU 1977:98. Pensionär 75.

SOU 2000:7. Långtidsutredningen 1999/2000.

SOU 1983:64. Ledighet för anhörigvård. Betänkande från Anhörigvårdskommittén.

SOU 1994:139. Ny socialtjänstlag. Huvudbetänkande av Socialtjänstkommittén. Stockholm.

SOU 1994:20. Reformerat pensionssystem. Betänkande av pensionsarbetsgruppen. Stockholm: Fritzes.

SOU 1997/98:113. Ny socialtjänstlag.

SOU 1997:170. Bemötande av äldre. Trygghet självbestämmande värdighet. Slutbetänkande av Utredningen om bemötande av äldre. Stockholm:Frtizes.

SOU 2001:79. Välfärdsbokslut för 1990-talet. Slutbetänkande/Kommittén Välfärdsbokslut. Stockholm: Fritzes.

SOU 2003:91. Vard och omsorg. Framtidens anhörigomsorg. Bilagedel C till Äldrepolitik för framtiden 100 steg till trygghet och utveckling med en åldrande befolkning.

Stark, Agneta och Regnér, Åsa (2001). I vems händer? Om arbete, genus, åldrande och omsorg i tre EU-länder. Tema Genus. Rapport Nr 1: 2001.

Statistik socialtjänst 2003:3. Äldre - vård och omsorg.

Steen, Bertil (red). (2003). Att bli äldre. H 70. De gerontologiska och geriatriska populationsstudierna i Göteborg 1971-2002. Göteborgs universitet, avdelningen för geriatrik.

Sundström, Gerdt (1983). Caring for the Aged in Welfare Society. Stockholm. Studies in Social Work:1. Stockholm:Liber (Akademisk avhandling).

Svallfors, Stefan (1996). Klass, kön och välfärdsstatlig integration: om attityder till välfärdspolitiken. I Palme, Joakim och Wennemo, Irene (red.). Generell välfärd Hot och möligheter? Välfärdsprojektet. Skriftserien Fakta/kunskap nr 3, s 65-86.

Svenska kommunförbundet. Socialtjänstlagen. En vägledning. Socialtjänstlag från 1 januari 1998 med kommentarer och praktiska anvisningar. Stockholm: Kommentus Förlag A-B.

Szebehely, Marta (1993). Hemtjänst eller anhörigvård? Förändringar under 80-talet. Stockholm: Socialstyrelsen.

Szebehely, Marta, Lingsom Susan \& Platz Merete (1997). Hemhjälpsutvecklingen: Samma problem, skilda lösningar? I Daatland Svein Olav (red). De siste årene Eldreomsorgen i Skandinavia 1960-95. Nova-rapport 22.

Szebehely, Marta (1998a) Omsorgsstat i förändring - svensk äldreomsorg i nordisk belysning. I Välfärden - verkan och samverkan. Rapport från forskarseminariet i Umeå 1998. Försäkringskasseförbundet Fakta Nr. 1.

Szebehely, Marta (1998b). "Hjälp i hemmet i nedskärningstid - hemtjänstens och anhörigas insatser för gamla kvinnor och män». I Sandqvist, A-M. (red). Åt var och en efter behov. Stockholm: Kommentus Förlag.

Szebehely, Marta (2000). Äldreomsorg I förändring. Knappare resurser och nya organisationsformer. I Välfärd, vård och omsorg. Antologi/ Kommittén Välfärdsbokslut/SOU 2000:38.

Szebehely, Marta och Eliasson, Rosmari (1991). "Hemtjänsten $i$ Sverige - myter och statistik". Nordiskt socialt arbete 1/91.

Szebehely, Marta, Fritzell, Johan och Lundberg, Olle (2001). Funktionshinder och välfärd. SOU 2001:56. Betänkande från Kommittén Välfärdsbokslut. Stockholm:Fritzes. 
Thorslund, Mats och Larsson, Kristina (2002). Äldres behov. En kunskapsöversikt och diskussion om framtiden. Stiftelsen Stockholms läns äldrecentrum.

Thulin, Ann-Britt (1992). Påfrestningar i hemtjänsten. I Eliasson, Rosmari (red). Egenheter och allmänheter. En antologi om omsorg och omsorgens villkor. Lund:Arkiv förlag.

Ungerson, Clare (1990). The Language of Care. Crossing the Boundaries. In Ungerson, C (ed.). Gender and Caring. Work and Welfare in Britain and Scandinavia, Harvest Wheatsheaf.

Wærness, Kari (1985). Välfärd och socialpolitik.
Sociologisk forskning nr 2-3.

Winqvist, Marianne (1985). SOS-syndromet - sorg, oro och samvetsförebråelser hos anhöriga tillpersoner med åldersdement beteende. Projektet Äldre i samhället - förr, nu och i framtiden. Arbetsrapport 24

www.carersonline.org.uk. The Carers (Equal Opportunities) Bill.

Zarit, S. Todd, P. \& Zarit, J. (1986). Subjective Burden of Husbands and wives as caregivers: A Longitudinal Study. The Gerontologist, vol. 26 no 3, pp. 260-266.

\section{Summary}

\section{Changed practices of public elderly care-a threat to society's goals of democracy and equality On increased burdens for informal carers}

The considerable decline in public elderly care in Sweden during the 1990s has led to increasing burdens for relatives. Today help is given only to the very oldest and most needy, in spite of the fact that elderly care is supposed to be given in relation to individual needs. Women from the working class are especially affected, both because they receive less assistance from home help service and because they are obliged to become family care providers. The purpose of the article is to question the shift of care responsibility from society to the family. The analyses focus on retired women as one group and women of working age as another (spouses and daughters). Despite poor physical capacity compared to men of the same age, retired women are obliged to contribute round-the-clock informal care work, often without assis- tance from the home help service. For women of working age, responsibility for an old family member can force them to reduce time spent doing paid work, with negative consequences for their income and pension. The alternative is double work, which may imply negative consequences for their health.

The Swedish welfare system is built on the individual. The change of practices in the public sector relies on a traditional form of family responsibility. From a juridical point of view, family responsibility in this sense no longer exists, and therefore protection for relatives in this type of situation does not exist. The elderly in need of help are also without legal rights since the primary concern is finding a relative who can care for the individual, rather than the individual's needs. 